\title{
A Stylistic Exploration of Headlines in Ghanaian Newspaper Editorials
}

\author{
James Gyimah Manu¹ (iD , Wisdom Mawuli Awuttey² \& Philip Kwame Freitas \\ 1 Department of English, Kwame Nkrumah University of Science and Technology (KNUST), Kumasi, Ghana. \\ 2 Department of Languages, Okuapemman School, Akropong-Akuapem, Ghana.
}

\begin{abstract}
Considering the role of newspaper editorials in shaping the opinions of the public on matters of national interest, the present study was carried out to explore how newspaper editorial headlines are constructed and packaged. A bottom-up stylistics approach was employed to ascertain some stylistic strategies or features in the headlines. It was revealed that Ghanaian editors employ several linguistic forms to trigger presuppositions and also use language devices or figures in order to affect the opinions of their readers, shape their understanding, and increase their interest to read the main text. The paper concludes that newspaper editorial headlines are not written arbitrarily but are carefully constructed to pack the greatest number of meanings in a small space. This study contributes to the existing knowledge in media discourse and stylistics in general. It presents headlines as independent text types which can be used as case studies in language classrooms to help students appreciate the application of language or literary concepts.
\end{abstract}

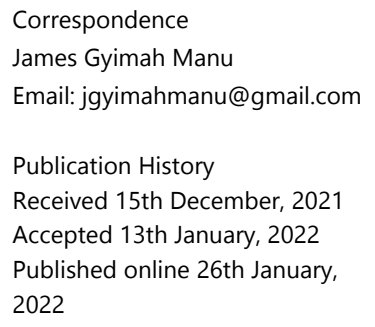

Keywords: Newspaper, editorial, headline, style and stylistics.

\section{INTRODUCTION}

A newspaper is a powerful medium which is used in the dissemination of local, national and international happenings. ${ }^{1}$ Ghana's socio-political history has seen the press as an important source of information flow to the citizenry and a massive source of subtly persuading people to take a particular cause of action. ${ }^{2}$ For example, newspapers were used in the fight for freedom of expression during the teething stage of Ghana's democracy. They have also been used to put forward various political and social ideologies. It is agreeable, therefore, to state that newspapers, and the media in general, are important aspects of the socio-political fabric of a country's existence.

One distinctive aspect of a newspaper is its editorial. A newspaper editorial is a brief account, which may be a statement or an article, of an issue of national interest written by an editor or a senior journalist of a newspaper firm. Such statements mostly embody the opinion, view or stance of the firm on the said issues. ${ }^{3}$

\footnotetext{
$1 \quad$ Wisdom Mawuli Awuttey, “A Study of Newspaper Reading Habits Among Members of the Debaters' Club of Okuapemman School, Akropong-Akuapem.” E-Journal of Humanities, Arts and Social Sciences (EHASS), (2020): 58-67.

2 Modestus Fosu, "A Linguistic Description of the Language of Ghanaian Newspapers: Implications for the Readability, Comprehensibility and Information Function of the Ghanaian Press." Ghana Journal of Linguistics 5, no. 1 (2016):1-36.

3 James Gyimah Manu, "Presupposition in Ghanaian and British Newspaper Editorials: A Comparative Study." Ghana Journal of Linguistics 9, no. 1 (2020): 18-45.
} 
As a unique form of journalistic writings, newspaper editorials are written to be argumentative and persuasive in order to be able to affect readers' opinions and consequently, 'accept the editorials' intended interpretation of news events". ${ }^{4}$ Therefore, based on the specific issue or event at hand, editors may write their editorials to, for example, criticize or attack the government on some policies and other issues of national interest; defend, praise or endorse projects and policies; appeal to the entire citizenry on a subject matter; and lastly, entertain the mass public. ${ }^{5}$ Thus, as a subgenre of the newspaper genre, newspaper editorials are important writings in shaping people's opinion on public issues and provide a valuable area of research in language use.

Dor explains that "headlines provide readers with an optimal ratio between contextual effect and processing effort, and direct readers to construct the optimal context for interpretation". ${ }^{6}$ Headlines are therefore linguistic items that summarize news reports and pertinently, frame the key content of a story and draw in the reader to read. ${ }^{7}$ For Reah, headlines are independent text types which possess various language features and functions within the newspaper text. ${ }^{8}$ As a language based text type, headlines are carefully written to capture an idea, promote an ideology or convince the readers to accept the opinions or positions presented in the text they introduce. ${ }^{9}$ These aspects and functions of the headline are even more crucial in newspaper editorial headlines as they are the starting point of the embodiment of newspaper editorials - that is, presenting arguments to convince readers to accept the views of the editor (and to some extent, that of the newspaper) on specific issues of national interest. It is against this background that this study set out to ascertain and examine some stylistic strategies that Ghanaian editors (that of the selected newspapers) use in crafting their headlines. To achieve this overarching objective, the following research questions were posed:

1. What stylistic strategies are used by Ghanaian newspaper editors in their headlines?

2. What is the functional significance of these strategies?

\section{STYLE AND STYLISTICS}

Style, in language use, is the peculiar or distinctive features of an individual's writing or speech. ${ }^{10}$ For Leech, style is "the way in which something is spoken, written, or performed". ${ }^{11} \mathrm{He}$ elaborates that it encompasses how words are used in sentence structure and the various figures of speech used by a writer or speaker. Leech and Short specify that style "refers to the way in which language is used in a given context, by a given person, for a given purpose, and so on". ${ }^{12}$ In effect, style is the various language choices that a writer or a speaker makes in order to communicate the intended meaning of what is said or written.

Stylistics has been defined in various ways by different scholars. To Widowson, it is the investigation of literary texts from a linguistic perspective. ${ }^{13}$ Short and Candlin reecho Widowson's definition by noting that it is a linguistic method in studying literary discourse. ${ }^{14}$ Crystal broadens the scope of stylistics from the

4 Alizera Bonyadi, and Moses Samuel. "Linguistic Nature of Presupposition in American and Persian Newspaper Editorials." International Journal of Linguistics 3, no. 1 (2011).

5 David R. Hall, “Materials Production: Theory and Practice.” In Innovations in English Language Teaching, edited by R. D. Hall and A. Hewings, (London: Routledge, 2001)229-239.

6 Daniel Dor, “On Newspaper Headlines as Relevance Optimizers.” Journal of Pragmatics, (2003): 695-721.

7 Colleen Cotter,. News talk: Investigating the language of journalism. (Cambridge: Cambridge Press, 2010); Michael White, "Cracking the Code of Press Headlines: From Difficulty to Opportunity for the Foreign Language Learner." Journal of English Studies 11, no. 1 (2011): 95-116; Alireza Bonyadi, and Moses Samuel. "Headlines in Newspaper Editorials: A Contrastive Study." Sage Open, 2013: 1-10.

8 Danuta Reah, The Language of Newspapers. (London: Routledge, 1998).

9 Folorunso Oloruntobi, "A Stylistic Analysis of Some Linguistic Devices in Newspaper Headlines: Nigerian Newspapers as a Case Study ." Studies in Pragmatics and Discourse Analysis, 2020: 47-57.

10 Karen C.Quackenbush, , Don A. Quackenbush, Pearl Krizza C. Epe, and Pia I. Trizza C. Epe. "Stylistics Analysis of Sonnet 18 by William Shakespeare.” International Journal of Applied Research, 2019: 233-237.

11 Geoffrey Neil Leech, A linguistic Guide to English Poetry. (London and New York: Longman Group Ltd., 1969).

12 Geoffrey Leech, and Mick Short. Style in Fiction. (London: Pearson Longman Group Ltd., 1981).

13 Henry George Widdowson,. Stylistics and the Teaching of English. (London: Pearson Longman Group Ltd., 1975).

14 Mick Short, and Christopher Candlin. "Teaching study skills for English literature." In Reading, Analysing and Teaching Literature, edited by Mick Short. (London: Longman, 1989). 
study of literary discourse to incorporate language use in general from a linguistic point of view. ${ }^{15}$ For Leech and Short, it is simply the study of style in the use of language. The crux of stylistics, therefore, is style and in effect, its (style) examination, explanation and description are the core concerns of scholars in this field. ${ }^{16}$

Stylistic analysis is "a method of textual interpretation in which primary of place is assigned to language." ${ }^{17}$ Language is made up of various levels, patterns and forms that make up the linguistic structure. These linguistic structures are the gateways to analyzing and interpreting texts, bringing out their functional significances. Therefore, an explicit exploration of the language features of a written or spoken text serves as a foundation, for the analyst or researcher, to project explanations on how and why certain meanings are communicated. Studying a text from the viewpoint of stylistics will therefore imply the scrutiny of the "how" and "why" of a text: its nature and interpretation. ${ }^{18}$

\section{METHODOLOGY}

This study is placed within the qualitative research paradigm. A qualitative study is one that affords the researcher the opportunity to do a critical observation of the data in order to offer a detailed description of the data. ${ }^{19}$ To achieve the objective of exploring some stylistic strategies or features in Ghanaian newspaper editorials, a bottom-up stylistic analysis was used. ${ }^{20}$ Here, the data was thoroughly studied by looking at the language make-up of the headlines to draw out some stylistic strategies, offer descriptions, interpretations and explanations to them. The stylistic strategies herein identified were not predetermined but were deduced from the data analyzed. This gave room for open-mindedness in the data observation process to identify as many stylistic features that were employed in the headlines.

\section{Data Collection Procedure}

Sixty (60) newspaper editorial headlines were randomly selected from the Daily Guide, and the Daily Graphic - thirty (30) from each newspaper. Although the selection of the editorial headlines was randomly done from editorials published in 2020, the selection of the said newspapers adopted a purposive sampling from the considerable number of newspapers in Ghana. The selected newspapers are listed among the best papers in terms of: readership and circulation across the country, commercial successes, and achievement of critical acclaims for quality in journalism in Ghana. The Daily Graphic and the Daily Guide are considered the most popular and widely read newspapers in Ghana - first and second, respectively. ${ }^{21}$ They are also seen as "the most dominant, credible and influential [in terms of] quality publications in Ghana" and have the tendency to affect the majority of readers in the country. ${ }^{22}$ As the current study seeks to examine the stylistic strategies used in newspaper editorial headlines by Ghanaian editors, it was crucial that newspapers that are widely accepted in the Ghanaian community were selected. The selected editorial headlines of the Daily Guide and the Daily Graphic were culled from their online repositories at https://dailyguidenetwork.com/category/editorial/ and https://www.graphic.com.gh/dailygraphic-editorials.html, respectively, on December 18, 2020.

\section{Coding of Data}

The sixty (60) editorial headlines were coded according to their respective newspaper for easy referencing in

15 David Crystal, Introducing Linguistics. (London: Penguin English, 1992).

16 Geoffrey Leech, and Mick Short. Style in Fiction: A Linguistic Introduction to English Fictional Prose. (London: Routledge, 2007).

17 Paul Simpson, Stylistics: A Resource Book for Students. (New York: Routledge, 2004).

18 Leech and Mick, Style in Fiction.

19 Earl R. Babbie, The Basics of Social Research. (Thomson/Wadsworth, 2005).

20 Sami Hussein Hakeem Barzani,. "A Stylistic Analysis of "After Twenty Years" By O. Henry." Turkish Online Journal of Qualitative Inquiry, 2021.

21 Samuel Kafewo, Ghana: Research Findings and Conclusions. African Media Development Initiative (AMDI), 2006; Daniel Kuehnhenrich, Entwicklung oder Profit?: Die staatliche und private Presse in Ghana. 2012.

22 Fosu, A Linguistic Description of the Language of Ghanaian Newspapers, 1-36. 
the analysis. "DGuH" and "DGrH" are used as reference codes for the editorial headlines of the Daily Guide and the Daily Graphic, respectively. Numbers are attached to the said codes for the purpose of specificity. The tables below give further details of the data.

Table 1: Selected Editorial Headlines of the Daily Guide

\begin{tabular}{|c|c|c|}
\hline Reference Code & Editorial Headline & Date Published \\
\hline DGuH 1 & The Mischief Continues & November 5, 2020 \\
\hline DGuH 2 & 'Stupid' Remark Uncouth & November 6, 2020 \\
\hline DGuH 3 & On Our Marks, Getting Set... & November 11,2020 \\
\hline DGuH 4 & Taming 'The Barking Dog' & November 16,2020 \\
\hline DGuH 5 & Bingo! They Have Made It! & November 17,2020 \\
\hline DGuH 6 & Open Defecation Still Prevalent & November 21,2020 \\
\hline DGuH 7 & What Is In The Flask? & October 6,2020 \\
\hline DGuH 8 & A Destructive Deluge Again & October 12,2020 \\
\hline DGuH 9 & Who Determines Flawed Rolls? & October 15,2020 \\
\hline DGuH 10 & The Chief Justice's Word & October 26,2020 \\
\hline DGuH 11 & They Will Fail In Their Tracks & October 27,2020 \\
\hline DGuH 12 & Unmasking A HIPC 'Deceit' & October 29,2020 \\
\hline DGuH 13 & Crocodile Tears For The Police Service & September 10,2020 \\
\hline DGuH 14 & Oh No. Not Again! & September 21,2020 \\
\hline DGuH 15 & The Last Evil Lap & September 23,2020 \\
\hline DGuH 16 & Cleric On NDC Mission & September 24,2020 \\
\hline DGuH 17 & Blood Over Land Ownership & September 26,2020 \\
\hline DGuH 18 & Talks With Rebels? No Way! & September 30,2020 \\
\hline DGuH 19 & Model SHSs: Another Novelty for Zongos & August 1,2020 \\
\hline DGuH 20 & Voter Register Sealed, Delivered & August 13, 2020 \\
\hline DGuH 21 & Crime is Crime Political or Otherwise & August 19, 2020 \\
\hline DGuH 22 & Okada Mentality Politics & August 24, 2020 \\
\hline DGuH 23 & Sealing Off The Violence Quarry & June 23,2020 \\
\hline DGuH 24 & There He Goes Again & June 25,2020 \\
\hline DGuH 25 & The Beauty Of The Rule Of Law & June 26,2020 \\
\hline DGuH 26 & Ghana's Pains: NDC, Covid-19 & June 29,2020 \\
\hline DGuH 27 & NDC's Covid-19 Effects & May 14,2020 \\
\hline DGuH 28 & Rigging? No Longer Feasible in Ghana & May 18,2020 \\
\hline DGuH 29 & Bawumia The Gold Standard & May 22,2020 \\
\hline DGuH 30 & The Rains Are Here Again & May 30,2020 \\
\hline
\end{tabular}

Table 2: Selected Editorial Headlines of the Daily Graphic

\begin{tabular}{|l|l|l|}
\hline Reference Code & Editorial Headline & Date Published \\
\hline DGrH 1 & New mortgage scheme good & November 7, 2020 \\
\hline DGrH 2 & Better collaboration key to making UN relevant & October 24, 2020 \\
\hline DGrH 3 & Let's stop the use of the dollar as second legal tender & October 10, 2020 \\
\hline DGrH 4 & Graphic is 70, hurray!! & October 5, 2020 \\
\hline DGrH 5 & Dealing with filing fees brouhaha & September 21, 2020 \\
\hline
\end{tabular}




\begin{tabular}{|l|l|l|}
\hline DGrH 6 & President's assurance laudable, timely & September 12, 2020 \\
\hline DGrH 7 & EC deserves commendation & September 10, 2020 \\
\hline DGrH 8 & Street Children deserve our attention & September 7, 2020 \\
\hline DGrH 9 & Let's push for Non-Custodial law & August 29, 2020 \\
\hline DGrH 10 & Being honest, truthful in the fight against corruption & August 12, 2020 \\
\hline DGrH 11 & Help establish breastfeeding as cultural norm & August 11, 2020 \\
\hline DGrH 12 & President's intervention, sign of father-for-all & August 10, 2020 \\
\hline DGrH 13 & Collaborate to protect children better & June 12, 2020 \\
\hline DGrH 14 & Tackling gender violence: one community at a time & June 11, 2020 \\
\hline DGrH 15 & Minimising learning disruptions & June 9, 2020 \\
\hline DGrH 16 & Food safety, a shared responsibility & June 8, 2020 \\
\hline DGrH 17 & Care for the environment must be every day & June 5, 2020 \\
\hline DGrH 18 & World Bicycle Day is here & June 4, 2020 \\
\hline DGrH 19 & Support AESL, others to deliver & June 3, 2020 \\
\hline DGrH 20 & Finding Cure for COVID-19: Researchers need full support & May 29, 2020 \\
\hline DGrH 21 & Pushing our democratic frontiers higher & May 28, 2020 \\
\hline DGrH 22 & Child abuse: an insidious epidemic & May 27, 2020 \\
\hline DGrH 23 & Making Africa next economic giant & May 26, 2020 \\
\hline DGrH 24 & Let the Spirit of Eid be with us & May 25, 2020 \\
\hline DGrH 25 & Disinfection against COVID-19 and Zoomlion & May 23, 2020 \\
\hline DGrH 26 & Nurses need our utmost care, attention & May 14, 2020 \\
\hline DGrH 27 & Tripartite engagements: having conversations of the times & May 13, 2020 \\
\hline DGrH 28 & Refreshing news, but let's get the vaccine & May 6, 2020 \\
\hline DGrH 29 & Media freedom enhances civil liberties & May 5, 2020 \\
\hline DGrH 30 & Assisting inventors; GSA must expand support & May 4, 2020 \\
\hline
\end{tabular}

\section{ANALYSIS \& DISCUSSION}

This section is aimed at exploring how the editorial headlines, as texts, are constructed to project and express meanings to readers. It revealed that Ghanaian editors packaged their headlines by employing varied language features and devices for some functional significance. Below are some of the said features that were drawn from the data.

\section{Presupposition in Ghanaian Newspaper Editorial Headlines}

It was evident, through the analysis, that the concept of presupposition is a dominant language feature of editorial headlines in the Ghanaian media landscape. Presupposition is "something the speaker assumes to be the case prior to making an utterance". ${ }^{23}$ For Richardson, presupposition is the implied claims that are intrinsic in the import of an utterance or text. ${ }^{24}$ Saeed also acknowledges that presupposition is part of the activities of packaging an utterance or a text and sees this language phenomenon as one of a number of inferences that the receiver (of the utterance or text) might make from what has been communicated. ${ }^{25}$ To this effect, Khaleel adds that language users use presuppositions as a form of "avoidance strategy" - it helps in communicating a lot of messages in a seemingly little or short language construction. ${ }^{26}$ Scholars, such

\footnotetext{
23 George Yule, Pragmatics. (Oxford: Oxford University Press, 1996).

24 John E. Richardson, Analyzing Newspapers: An approach from critical discourse analysis. (NY: Palgrave, Macmillan, 2007).

25 John I. Saeed, Semantics. (Oxford: Blackwell Publishing, 1997).

26 Layth Muthana Khaleel, “An Analysis of Presupposition Triggers in English Journalistic Texts.” J. Of College of Education For Women (Baghdad University) 21, no. 2 (2010): 523-550.
} 
as Yule, Saeed, Khaleel, and Alcarza, have identified several linguistic structures or forms that give rise to or trigger presuppositions. ${ }^{27}$ Such linguistic forms are popularly known as presupposition triggers in the domain of presuppositional analysis. ${ }^{28}$ The analysis revealed varied presupposition triggers in the editorial headlines. These identified triggers are grouped under the three (3) main types of presupposition (Existential, Lexical and Structural Presuppositions) espoused by Khaleel. ${ }^{29}$ In the analysis, "presupposes" is marked with " $>>$ " as a convention in the field. The linguistic forms that specifically trigger presupposition in the headlines are put in italics.

\section{Existential Presupposition}

In this type of presupposition, the existence of an entity is assumed by the speaker in an utterance. This is evident in the example, "Mary's brother bought three horses." 30 Here, the speaker assumes the existence of someone called Mary and that she has a brother who has bought three horses. In this case, the receiver of such an utterance may tend to infer this implied claim or assume the truth value of this claim. The analysis revealed the use of definite noun phrases and possessive constructions as triggers of this type of presupposition.

\section{Definite Noun Phrases}

The following are the definite noun phrases that trigger existential presupposition in the editorial headlines.

1. The Mischief Continues $>>$ There is mischief (DGuH 1)

2. Taming 'The Barking Dog' >> There is a barking dog (DGuH 4)

3. The last evil lap $>>$ There is a last evil lap (DGuH 15)

4. Sealing off the violence quarry $>>$ There is a violence quarry (DGuH 23)

5. The beauty of the rule of law $>>$ The rule of law has beauty

6. Bawumia the gold standard $\gg>$ There is a gold standard [which is Bawumia] (DGuH 29)

It can be deduced that the noun phrases of the kind above are used by the editors to push forward the truth value of the existence of the entities named. In this case, the reader is therefore made to accept that there is a mischief, a barking dog, an evil lap, a violence quarry, beauty in the rule of law, and a gold standard as presupposed in the constructions above, respectively. Because these are headlines, the presupposed existence of these entities named may draw the reader's attention to enter an inquisition exercise by reading the entire text to know the said mischief, barking dog or evil lap. This may serve as a starting point in persuading the reader to accept the details or descriptions given to these entities.

\section{Possessive Constructions}

The analysis of the data showed that the "apostrophe s", ('s), which is used to express the belonging or possession of nouns and "our", which also enacts some possession, presuppose the existence of the noun elements so named in their constructions. The following exemplifies the possessive construction as a presupposition trigger in the data.

7. The Chief Justice's word $>>$ The Chief Justice has a word (DGuH 10)

8. Ghana's pains: NDC, Covid-19>> Ghana has pains [which are NDC and Covid-19] (DGuH 26)

9. President's assurance laudable, timely $>>$ The President has an assurance [which is timely and laudable] (DGrH 6)

10.President's intervention, sign of father-for-all $>>$ The President has an intervention [which is a sign of father-for-all] (DGrH 12)

\footnotetext{
27 Enrique Alcarza, Stylistics in the framework of pragmatics. (Sevilla: de la Universidad de Sevilla, 1999).

28 Saeed, Semantics.

29 Khaleel, “An Analysis of Presupposition Triggers in English Journalistic Texts.” 523-550.

30 Yule, Pragmatics.
} 
The use of the 's in the constructions above asserts the truism of the propositions - that is the existence of: a word from the Chief Justice, the pains that Ghana has, the assurance, and the intervention of the President. The reader is therefore made to accept the presupposed meanings with some truth value. The use of "our" shows some form of collective possession and triggers the existential presupposition. ${ }^{31}$

The analysis also revealed that the editors projected themselves as part of a group which the reader belongs, through the use of "our" in some headlines. Therefore, the existence of the entity which is presupposed can be said to be a collective possession of the editor and the reader. For Gyimah Manu, the editors' use of this "may appeal to the senses of their readers and therefore manage to convince or persuade them into accepting their opinions". ${ }^{32}$ The constructions below exemplify the above.

11. On Our Marks, Getting Set ... >> We [editor and reader] have a mark [which we are getting set on] (DGuH 3)

12. Street Children deserve our attention $>>$ We [editor and reader] have attention [to give street children] (DGrH 8)

13. Pushing our democratic frontiers higher $>>$ We [editor and reader] have democratic frontiers (DGrH 21)

14. Nurses need our utmost care, attention $>>$ We [editor and reader] have utmost care, attention [which nurses need] (DGrH 26)

It can also be argued that the presupposing "we" is referent to the members of the Ghanaian community, of which the editor, and possibly the reader, are part of.

\section{Lexical Presupposition}

This type of presupposition is triggered by the use of certain words or lexical items which enact presupposition in their linguistic environment. The observation of the data revealed the use of iterative items and conventional items as triggers of the aforementioned presupposition.

\section{Iterative Items/Words}

For Crystal, an event is said to be iterative when such an event "takes place repeatedly". ${ }^{33}$ Khaleel refers to words which give rise to the repeated nature of events or actions as iteratives. ${ }^{34}$ The data revealed some verbs and adverbs that are iterative, which consequently trigger some presupposed meaning. The following were culled from the data:

15. The Mischief Continues $>>$ The mischief keeps on happening or the mischief has been going on $(\mathrm{DGuH} 1)$

16. Open Defecation Still Prevalent $>>$ Open defecation has been prevalent (DGuH 6)

17. A destructive deluge again $>>$ A destructive deluge has happened before (DGuH 8)

18. Oh no. Not again! >> Something has been happening [which must be stopped] (DGuH 14)

19. There he goes again $>>\mathrm{He}$ has gone there before (DGuH 24)

20. The rains are here again $>>$ The rains have been here before (DGuH 30)

It must be stated that apart from continue, still and, again, the phrase, no longer, was also identified as an iterative item in the data. It (no longer) iterates an action although this iterative action is signaled to have been brought to a close - this may be said to be a negative iterative. ${ }^{35}$ Find the case below:

Rigging?

31 Gyimah Manu,. "Presupposition in Ghanaian and British Newspaper Editorials", 18-45.

32 Gyimah Manu,. "Presupposition in Ghanaian and British Newspaper Editorials", 18-45.

33 David Crystal, A Dictionary of Linguistics and Phonetics. (Oxford: Blackwell Publishers Ltd., 1997).

34 Khaleel, "An Analysis of Presupposition Triggers in English Journalistic Texts." 523-550.

35 Gyimah Manu, "Presupposition in Ghanaian and British Newspaper Editorials", 18-45. 


\section{No longer feasible in Ghana >> Rigging has been feasible in Ghana before (DGuH 28)}

\section{Conventional Items/Words}

Certain constructions may presuppose some meanings because of the use of lexical items which may give rise to some conventional meanings. These presuppositions, according to Levinson, are tied to these lexical items. ${ }^{36}$ It was noted from the data that the use of some verb forms, in the headlines, led to some conventional meanings which are presupposed. The reader is subtly persuaded about the veracity of the presupposed meanings which were activated by the use of conventional items in constructions. Below are such cases from the data:

22. Taming 'The Barking Dog' >> The barking dog has been wild (DGuH 4)

23. Sealing off the violence quarry $>>$ The violence quarry was opened (DGuH 23)

24. Let's stop the use of the dollar as second legal tender $>>$ The dollar has been used as a second legal tender (DGrH 3)

25. Dealing with filing fees brouhaha $>>$ The filing fees brouhaha is a challenge or problem that has to be solved (DGrH 5)

26. Minimising learning disruptions $>>$ Learning disruptions have been high (DGrH 15)

\section{Structural Presupposition}

In some cases, language users select certain sentence structures "to treat information as presupposed (i.e., assumed to be true) and hence to be accepted as true by the listener." ${ }^{37}$ In the Wh-interrogative, "When did he travel?", the presupposing idea can be highlighted as "He traveled". The listener of the afore-given interrogative is left to assume that the one being talked about traveled.

\section{Wh-Interrogative/Question}

A Wh-interrogative is a functional type of sentence that is formed with a preceding wh-word, such as who, whom, whose and where, and requires a response or answer. As espoused by several scholars (for example, Khaleel, and Bonyadi and Samuel), the wh-question triggers presuppositions. It was observed that this type of interrogative was employed in the data as given below, with their presupposed meanings. ${ }^{38}$ The reader is somewhat inherently convinced about the certainty of the presupposed statement of the interrogative.

27. What is in the flask? $>>$ There is something in the flask (DGuH 7)

28. Who determines flawed rolls? >> Someone determines flawed rolls (DGuH 9)

\section{Language Devices/Figures in Ghanaian Newspaper Editorial Headlines}

A language device is implied when various units of language, such as words, phrases and clauses, are used in a manner in which they convey elevated meanings - i.e. when they communicate meanings which are different from that which are simple or literal. Writers have an onus to decide how-to put-up words to communicate their intended meanings and purpose. Consequently, writers have the responsibility to use the appropriate language devices to make their writing evocative, memorable, and above all, disseminate the purported intent. The analysis brought out a considerable number of language or literary devices, or figures of speech, which were employed in the editorial headlines sampled for this analysis. It must be stated that, for strong arguments to be raised in the analysis of this section, the researchers of this study did not present language devices which had one (1) occurrence of use in the data.

\section{Caesura}

In simple terms, caesura can be said to be a pause or break in any grouping of words to denote the end and the

36 Stephen C. Levinson,. Pragmatics. (Cambridge: Cambridge University Press, 1983).

37 Yule, Pragmatics.

38 Khaleel, “An Analysis of Presupposition Triggers in English Journalistic Texts.” 523-550; Bonyadi, and Samuel. "Linguistic Nature of Presupposition in American and Persian Newspaper Editorials." 
start of a new phrase - it may also coincide with a pause between clauses or sentences. ${ }^{39}$ In the data, editors employed punctuation marks such as the comma (,), colon (:), and semicolon (;) to break their headlines mainly into two effective phrases, to grab their audience's attention to the informative parts of the headlines or the focus of their editorials. Below are the cases that were drawn from the data.

29. Ghana's pains: NDC, COVID-19 (DGuH 26)

30. Bawumia, the gold standard (DGuH 29)

31. Voter's register, sealed and delivered (DGuH 20)

32. On our marks, getting set ... (DGuH 3)

33. Child abuse, an insidious epidemic (DGrH 22)

34. President's intervention, sign of father-for-all (DGrH 12)

35. Tackling gender violence: one community at a time (DGrH 14)

36. Tripartite engagements: having conversations of times (DGrH 27)

37. Food safety, a shared responsibility (DGrH 16)

38. Finding a cure for COVID-19: Researchers need full support (DGrH 20)

39. Refreshing news, but let's get the vaccine (DGrH 28)

40. Assisting inventors; GSA must expand support (DGrH 30)

It is clear from some of the examples above that, editors also employ breaks or pauses in their headlines to avoid clauses or sentences by mostly ellipting or omitting the verbal elements. By so doing, they are able to capture their headlines in phrases to disseminate the main thrust of their editorials in simple terms (phrases) to their readers. Consider the revised versions of examples 29, 30, 31 and 37 which are 41, 42, 43 and 44, respectively.

41. Ghana's pains [are] NDC, [and] COVID-19

42. Bawumia [is] the gold standard

43. Voter's register [has been] sealed and delivered

44. Food safety [is] a shared responsibility

\section{Ellipsis}

Baldick explains ellipsis as an omission of a word or words from a sentence which may not inhibit the understanding or meaning of the sentence. He also notes the sequence of three (3) dots (...), which shows the omission of some elements, as ellipsis. ${ }^{40}$ Examples of such from the data are given below.

45. Bawumia, [is] the gold standard (DGuH 29)

46. Voter's register, [has been] sealed and delivered (DGuH 20)

47. On our marks, getting set ... (DGuH 3)

48. Child abuse, [is] an insidious epidemic (DGrH 22)

49. Making Africa [the] next economic giant (DGrH 23)

50. President's intervention, [is a] sign of father-for-all (DGrH 12)

51. Food safety, [is] a shared responsibility (DGrH 16)

The meticulous use of time and space are important aspects of media journalism. In journalistic writings within the print media, writers have the arduous task to make the best use of every little space because of the commercial benefits attached to space. Further, editors have the onus to capture or summarize the key content of their editorials into headlines for their readers. It can therefore be put forward that for the purposes

39 Chris Baldick, The Concise Oxford Dictionary of Literary Terms. (New York: Oxford University Press, New York, 2001).

40 Baldick, The Concise Oxford Dictionary of Literary Terms. 
stated above, editors of the selected Ghanaian newspapers employ ellipsis as a form of avoidance strategy to limit space and to help in their quest to summarize the key contents of their editorials.

\section{Exclamation}

An exclamation (also known as 'exclamatio') is a construction which expresses a high sense of emotion (excitement, sadness, urgency etc.) through an abrupt use of the exclamation mark. Such constructions were considerably employed by the Ghanaian editors as their headlines. Such headlines trigger some sort of emotions in the reader at the first ask, which may consequently serve as a stimulant for the reader's interest to read on.

52. Oh No! Not Again! (DGuH 14)

53. Talks with rebels? No way! (DGuH 18)

54. Bingo! They made it! (DGuH 5)

55. Graphic is 70, hurray!! (DGrH 4)

\section{Metaphor}

Metaphor is a seeming comparison between two or more entities without an explicit word which aids the comparison, such as "like" and "as". This comparison suggests some commonalities or resemblances between the entities being compared.

56. Bawumia, the gold standard (DGuH 29)

57. Okada mentality politics (DGuH 22)

58. Child abuse, an insidious epidemic (DGrH 22)

One can deduce from the examples (56-58) above that Bawumia, politics and child abuse are understood in terms of gold standard (an accepted or valuable level of measure or comparison), okada mentality (the attitude and mindset of commercial motorcycle riders), and epidemic (an infectious disease which is widespread), respectively. This is to say that one's understanding or idea of gold standard, okada mentality, and epidemic is used in the meaning-making process to fully understand who Bawumia is, what the politics being put across is like, and the nature of child abuse. Metaphors are therefore employed in the headlines to give the reader some level of understanding of the key contents to be presented in the main body - it aids summarization and to some extent, persuades the reader to accept the ideas which may be deciphered about the entities in the indirect comparison.

\section{Rhetorical question}

This is a question which does not require a response, reply or an answer. Cases from the data are given below.

59. What is in the Flask? (DGuH 7)

60. Who determines flawed rolls? (DGuH 9)

It can be argued from the above that such questions are posed for the creation of emphasis and provocation of thought on the part of the reader. It is clear that the wh-questions above do not demand an answer on whether or not there is something in the flask or someone who determines flawed rolls, but to emphasize the need of recognizing that there is something in the flask and there is someone who determines flawed rolls. This consequently provokes the thinking of the reader in order to decipher what may be in the flask and who may determine flawed rolls, and further draw interest to the main text. 


\section{Hypophora}

This is a language occurrence where a writer or speaker poses a question and answers that with immediacy. A hypophora can therefore be said to have two parts: the first as the question and the second, the answer. This figure is also known as 'anthypophora' or 'antipophora'. From the data, it can be deduced that editors used the first part of the hypophora to present a critical issue in the national interest to the readers and used the second part to present their strong opinion about the said issue. The writer anticipates the critical question about the issue which may be lingering in the minds of the citizenry, poses it to them, and then presents his or her opinion as the answer to this mind-boggling question. This may be an effective way to persuade the reader into accepting the writer's opinion.

1. Talks with rebels? No way! (DGuH 18)

2. Rigging? No longer feasible in Ghana (DGuH 28)

\section{Imagery}

The use of language to evoke sense-impressions, feelings or ideas. It comprises the set of images that are employed in language which need not be just 'mental pictures' but may appeal to senses other than sight. The images invoked in the selected headlines may predominantly appeal to the sense of sight of readers. This aids the reader to clearly see, through some sort of imagination or picturing, what the writer is putting across to aid understanding and share in the opinion. A sensory experience aimed at understanding and persuasion.

1. Unmasking a HIPC 'Deceit' (DGuH 12)

2. They will fail in their tracks (DGuH 11)

3. Sealing off the violence quarry (DGuH 23)

\section{FINDINGS}

The analysis brought out two main stylistic strategies used by Ghanaian newspaper editors (as per this study) in their headlines: presupposition (existential, lexical, and structural) and some language devices (caesura, ellipsis, exclamation, metaphor, rhetorical question, hypophora and imagery). In general, the analysis and discussion revealed that newspaper editorial headlines do not only serve to introduce and summarize the focus or key content of editorials but also aimed at influencing the reader's opinion about the focus, shaping the reader's understanding of the focus and drawing the reader's attention and interest to the subject of the editorial text. These functions of the editorial headlines were carried out through the stylistic strategies aforementioned. Newspaper editorials are written to be argumentative and persuasive in order to be able to affect readers' opinions on issues of interest. ${ }^{41}$ The headline of the newspaper editorial serves as the starting point of this all-important duty. The present study suggests that presupposition was deployed by the Ghanaian newspaper editors of the selected editorials as a persuasive strategy to influence the reader's opinions on the subject at hand. The views of the editors and their newspapers expressed in the headlines are presented as "facts" or possibly, "as if as facts", through presuppositions.

The existential presupposition was enacted by the use of definite noun phrases and possessive constructions. These linguistic forms push forward the truth values or assert the truism of the existence of the entities named. The analysis also revealed that the editors present themselves as part of a group that the reader belongs in their use of "our" to indicate collective possession of the entity named between them and the reader. This congeniality created helps in the acceptance of the presupposed meaning on the part of the reader. On lexical presupposition, the reader is convinced about the repeated nature of the event or action prompted by the use of iterative items such as "continues", "still", "again", and "no longer". Further, the reader is subtly persuaded to accept the presupposed meanings activated by the use of conventional items such as "taming”, "sealing off”, "stop", "dealing with", and "minimizing”. Structurally, the presupposed

41 Hall, "Materials Production: Theory and Practice.", 229-239; Bonyadi, and Samuel. "Linguistic Nature of

Presupposition in American and Persian Newspaper Editorials." 
statement of the wh-interrogative expresses some level of "factiveness" hence, may serve to convince the reader into accepting that as a fact.

The present study also suggests that some language devices were employed in the data for rhetorical effect. Rhetoric as a concept is connected with aspects of communication that aim at persuasion. ${ }^{42}$ It also aims at the use of artful or aesthetic means to influence interactions through logic and emotion. ${ }^{43}$ The analysis and discussion revealed interesting findings on the functional significance of language devices. The caesura was noted to break the headlines into phrases to attract readers' attention to the focus areas of the editorial thereby influencing the interest of the readers to read the main text for details. The pauses that come with the break of the headlines into phrases also affect or project the headline to be emphatic or even, "factive". Consider this: "Bawumia, the gold standard" (DGuH 29); "Ghana's pains: NDC, COVID-19" (DGuH 26); "Child abuse, an insidious epidemic" (DGrH 22). Exclamation as a language device was also used in the headlines to appeal to the emotions of the readers and to sustain their attention and interest in the reportage.

The metaphor was used in the writers' attempt to explain the key concepts or entities in the headlines. Here, the writer evokes the reader's understanding of a common concept or entity to explain another concept or entity which the writer aims at. The reader is therefore made to accept the comparison between the entities or concepts evoked by the writer - his opinion or understanding of the target entity or concept is influenced by the writer. Rhetorical questions were used to create emphasis on an idea the writer wants to disseminate and for the provocation of thought on the part of the reader. This is used as a rhetorical strategy to sustain the interest of the reader to read on (e.g., "Who determines flawed rolls?" (DGuH 9)). In hypophora, the writer poses a question and goes on to answer same. Ghanaian newspaper editors used this device to assert their views or statements to their audience in a question-and-answer format. This was used as a rhetorical strategy to help in the persuasion of the reader into accepting the response or reply as the truth (e.g., "Rigging? No longer feasible in Ghana" (DGuH 28)). The use of imagery in the data provides a sensory or mental experience for the reader to understand and accept the main idea(s) being put across by the writer. It is important to also note that the ellipsis was employed in the headlines in the editors' quest to summarize and frame the key contents of the reportages.

\section{CONCLUSION}

Considering the importance of headlines as linguistic items that have the power to attract a reader to read or repel a reader from same, and the importance of newspaper editorials in shaping the opinions of a community on issues, the present study was carried out to explore how newspaper editorial headlines are constructed in the Ghanaian media landscape. It was revealed that Ghanaian editors, per this paper, employ, in their headlines, several linguistic forms to trigger presuppositions (existential, lexical, structural) and also use several language devices or figures (as aforementioned), in order to affect the opinions of their readers, shape their understanding and increase their interest to read the main text. This is to say that newspaper editorial headlines are not written arbitrarily but are carefully constructed to pack the greatest number of meanings in a small space for purposes explored above. Owing to the fact that journalistic writings, such as editorials, provide a unique domain of writing (as shown by this paper), they can be used as instructional materials in the language classroom to help students appreciate how various language concepts are applied in real-life situations of writing.

\footnotetext{
42 Ulla Connor, Contrastive rhetoric: Cross-cultural aspects of second-language writing. (New York, NY: Cambridge University Press, 1996).

43 Farzaneh Khodabandeh, "A Contrastive Analysis of English and Persian Newspaper Headlines.” The Linguistics Journal 2, no. 1 (2019).
} 


\section{BIBLIOGRAPHY}

Alcarza, Enrique. Stylistics in the framework of pragmatics. Sevilla: de la Universidad de Sevilla, 1999. ISBN 84-472-0489-8

Awuttey, Wisdom Mawuli. “A Study of Newspaper Reading Habits Among Members of the Debaters' Club of Okuapemman School, Akropong-Akuapem.” E-Journal of Humanities, Arts and Social Sciences (EHASS), 2020: 58-67. https://doi.org/10.38159/ehass.2020062

Babbie, Earl R. The Basics of Social Research. Thomson/Wadsworth, 2005. www.ascdegreecollege.ac.in/wp-content/uploads/2020/12/Babbie-Earl-R.-The-Basics-ofSocial-Research.pdf

Baldick, Chris. The Concise Oxford Dictionary of Literary Terms. New York: Oxford University Press, New York, 2001.

Barzani, Sami Hussein Hakeem. “A Stylistic Analysis of “After Twenty Years” By O. Henry.” Turkish Online Journal of Qualitative Inquiry, 2021. [Researchgate]

Bonyadi, Alireza, and Moses Samuel. "Headlines in Newspaper Editorials: A Contrastive Study." Sage Open, 2013: 1-10. https://doi.org/10.1177\%2F2158244013494863

Bonyadi, Alizera, and Moses Samuel. "Linguistic Nature of Presupposition in American and Persian Newspaper Editorials.” International Journal of Linguistics 3, no. 1 (2011). http://dx.doi.org/10.5296/ijl.v3i1.554

Connor, Ulla. Contrastive rhetoric: Cross-cultural aspects of second-language writing. New York, NY: Cambridge University Press, 1996. https://doi.org/10.1017/S0272263198261055

Cotter, Colleen. News talk: Investigating the Language of Journalism. Cambridge: Cambridge Press, 2010. https://doi.org/10.1017/S0047404512000097

Crystal, David. A Dictionary of Linguistics and Phonetics. Oxford: Blackwell Publishers Ltd., 1997.

Crystal, David. Introducing Linguistics. London: Penguin English, 1992.

Dor, Daniel. “On Newspaper Headlines as Relevance Optimizers.” Journal of Pragmatics, 2003: 695-721. https://doi.org/10.1016/S0378-2166(02)00134-0

Fosu, Modestus. "A Linguistic Description of the Language of Ghanaian Newspapers: Implications for the Readability, Comprehensibility and Information Function of the Ghanaian Press." Ghana Journal of Linguistics 5, no. 1 (2016): 1-36. http://dx.doi.org/10.4314/gjl.v5i1.62

Gyimah Manu, James. "Presupposition in Ghanaian and British Newspaper Editorials: A Comparative Study." Ghana Journal of Linguistics 9, no. 1 (2020): 18-45. http://dx.doi.org/10.4314/gil.v9i1.2

Hall, David R. "Materials Production: Theory and Practice." In Innovations in English Language Teaching, edited by R. D. Hall and A. Hewings, 229-239. London: Routledge, 2001.

Kafewo, Samuel. Ghana: Research Findings and Conclusions. African Media Development Initiative (AMDI), 2006.

http://downloads.bbc.co.uk/worldservice/trust/pdf/AMDI/ghana/amdi_ghana full_report.pdf

Khaleel, Layth Muthana. "An Analysis of Presupposition Triggers in English Journalistic Texts.” J. Of College of Education For Women (Baghdad University) 21, no. 2 (2010): 523-550. https://www.iasj.net/iasj/download/e069fbccca0a9684

Khodabandeh, Farzaneh. "A Contrastive Analysis of English and Persian Newspaper Headlines.” The Linguistics Journal 2, no. 1 (2019).[Google Scholar]

Kuehnhenrich, Daniel. Entwicklung oder Profit?: Die staatliche und private Presse in Ghana. 2012. https://doi.org/10.25969/mediarep/13168

Leech, Geoffrey Neil. A linguistic Guide to English Poetry. London and New York: Longman Group Ltd., 1969.

Leech, Geoffrey, and Mick Short. Style in Fiction. London: Pearson Longman Group Ltd., 1981. . Style in Fiction: A Linguistic Introduction to English Fictional Prose. London: Routledge, 2007.

Levinson, Stephen C. Pragmatics. Cambridge: Cambridge University Press, 1983. 
Oloruntobi, Folorunso. "A Stylistic Analysis of Some Linguistic Devices in Newspaper Headlines: Nigerian Newspapers as a Case Study ." Studies in Pragmatics and Discourse Analysis, 2020: 47-57. https://doi.org/10.48185/spda.v1i1.75

Quackenbush, Karen C., Don A. Quackenbush, Pearl Krizza C. Epe, and Pia I. Trizza C. Epe. "Stylistics Analysis of Sonnet 18 by William Shakespeare." International Journal of Applied Research, 2019: 233-237. http://dx.doi.org/10.29322/IJSRP.9.03.2019.p8723

Reah, Danuta. The Language of Newspapers. London: Routledge, 1998.

Richardson, John E. Analyzing Newspapers: An approach from critical discourse analysis. NY: Palgrave, Macmillan, 2007.

Saeed, John I. Semantics. Oxford: Blackwell Publishing, 1997. http://coursdelinguistique.free.fr/Ressources/Semantics.pdf

Short, Mick, and Christopher Candlin. "Teaching study skills for English literature.” In Reading, Analysing and Teaching Literature, edited by Mick Short. London: Longman, 1989.

Simpson, Paul. Stylistics: A Resource Book for Students. New York: Routledge , 2004. https://uogbooks.files.wordpress.com/2014/10/stylistics-a-resource-book-for-students-paulsimpson.pdf

White, Michael. "Cracking the Code of Press Headlines: From Difficulty to Opportunity for the Foreign Language Learner.” Journal of English Studies 11, no. 1 (2011): 95-116. https://files.eric.ed.gov/fulltext/EJ952970.pdf

Widdowson, Henry George. Stylistics and the Teaching of English. London: Pearson Longman Group Ltd., 1975.

Yule, George. Pragmatics. Oxford: Oxford University Press, 1996.

\section{ABOUT AUTHORS}

James Gyimah Manu is an Assistant Lecturer at the Department of English, Kwame Nkrumah University of Science and Technology (KNUST), Kumasi, Ghana. He holds MPhil and BA in English from KNUST. His research interests cover topics in the areas of Stylistics, Syntax, Semantics and Pragmatics. Currently, his research is focused on how language is used within the Ghanaian media landscape.

Wisdom Mawuli Awuttey is an English Tutor at the Department of Languages, Okuapemman School, Akropong-Akuapem, Ghana. He holds MA in Communication and Media Studies from the University of Education, Winneba, Ghana, and BA in English from KNUST. His research interests cover issues in the area of media discourse and language use in general. His current research examined the newspaper reading habits among members of the debaters' club of the Okuapemman School.

Philip Kwame Freitas is a former Teaching Assistant at the Department of English, Kwame Nkrumah University of Science and Technology (KNUST), Kumasi, Ghana and an MPhil Candidate in the same department. He has research interests in bildungsroman in African novels, postcolonial literature, and literature of the diaspora. 